\title{
Surgical treatment of heart failure: a hot topic
}

\section{Tratamento cirúrgico da insuficiência cardíaca: uma área em ebulição}

\author{
Paulo Manuel Pêgo-Fernandes', Rosangela Monteiro"
}

Over recent decades, the alarming increase in the incidence of heart failure has led to recognition that there is a veritable epidemic of this disease in the Western world. ${ }^{1,2}$ The incidence of heart failure has been estimated to be $2 \%$ in the United States and Europe, and it may reach $13 \%$ among the elderly population. ${ }^{3}$

Around $10 \%$ of the patients with heart failure progress to more severe forms of the disease. These are patients who, despite optimized clinical treatment, continue to present symptoms. With disease progression, their quality of life deteriorates and their mortality rate is high. ${ }^{4-6}$

In Brazil, the main etiology for heart failure is chronic ischemic heart disease in association with high blood pressure. However, many diseases may lead to the final stage of heart failure, such as idiopathic dilated myocardiopathy, valve diseases, metabolic and inflammatory disorders. ${ }^{7}$ The final outcome for most of these diseases is heart remodeling, characterized by myocyte hypertrophy and dilatation of the cavities, thus leading to a more spherical shape for the left ventricle and reduction of the ejection fraction. ${ }^{7}$

Thus, proposals for new therapies and improvements in the existing therapies have been seen, resulting in significantly better treatment and management for heart failure patients. Among these techniques, the development of new medications and pharmacological regimens, ${ }^{8,9}$ cardiac resynchronization therapy, ${ }^{10}$ mechanical devices to assist the circulation, cell therapy, ${ }^{11}$ cardiovascular rehabilitation programs with exercises ${ }^{4}$ and thoracic sympathectomy, ${ }^{12}$ among others, can be highlighted. Within this context, heart surgery has an important role. ${ }^{13}$

Heart transplantation is still the best option, through providing increased quality of life and longer survival. ${ }^{14,15}$ This procedure has been presenting results of greater consistency, thanks to improvements and adaptations in recipient selection, donor maintenance, new immunosuppressant drugs, advances in diagnosing rejection and experience of post-transplant management. ${ }^{9,16}$ Nonetheless, transplantation presents many limitations, including the need for immunosuppressive therapy, high costs, donor shortage, high mortality in the waiting lists and very rigid indication criteria.

In parallel, devices for mechanically assisted circulation have been gaining space over recent years. These devices may be indicated with the aim of helping a debilitated heart to pump blood and can be used as bridging prior to transplantation, which gives such patients the chance to safely wait for a compatible donor. They can be used for recuperation therapy, in which the device not only maintains the patient's life in critical situations but also allows recovery of cardiac function. In these cases, the device can subsequently be removed. Lastly, these devices can be used as destination therapy, in which they are applied in a permanent manner when the patient presents contraindications against heart transplantation. ${ }^{17-19}$

The use of assisted circulation devices has become well established internationally. However, in Brazil, only limited experience with these devices has been acquired. There have been few clinical cases or experimental studies, despite the existence of large numbers of patients who would benefit from such therapy. ${ }^{18-24}$ The main barriers against wider use of these devices are their high cost and the almost absolute dependence on products on the international market. ${ }^{19}$

One of the principal characteristics of chronic heart failure is dilatation of the left ventricle, with progressive dilatation of the mitral ring and displacement of the papillary muscles. The presence of mitral failure in heart failure cases is a predictive factor for worsened quality of life and mortality. ${ }^{25,26}$ Several studies have demonstrated that correcting the mitral failure in patients with severe left ventricular dysfunction, either through valvuloplasty or valve replacement with preservation of the subvalvular apparatus, is associated with low mortality due to the operation, symptom relief and improved short and medium-term survival.

IMD, PhD. Associate Professor, Discipline of Thoracic Surgery, Instituto do Coração (InCor), Hospital das Clínicas, Faculdade de Medicina, Universidade de São Paulo (HCFMUSP), São Paulo, Brazil.

"Chief Biologist, Discipline of Thoracic Surgery, Instituto do Coração (InCor), Hospital das Clínicas, Faculdade de Medicina, Universidade de São Paulo (HCFMUSP), São Paulo, Brazil. 
Disorders of intraventricular conduction are present in around $25-50 \%$ of individuals with heart failure, and left-branch block is the most frequent of these. ${ }^{27}$ Within such scenarios, cardiac resynchronization therapy has been used as adjuvant treatment in patients with heart failure who are refractory to optimized drug therapy. ${ }^{27,28}$ Diminished mortality, improved symptoms and improved quality of life, along with cardiac remodeling, have been reported by several authors, resulting from using cardiac resynchronization therapy for individuals with health failure. ${ }^{10,27}$ However, because of the high cost and the fact that therapeutic failure occurs in around one third of the patients undergoing this intervention, several investigations have been conducted with the aim of identifying patients who might have greater benefit from this procedure. $^{10}$

The purpose of reverse remodeling surgery on the left ventricle is to reduce the volume of the left ventricular cavity and reestablish its shape prior to remodeling, together with complete revascularization. ${ }^{29}$

More recently, within our setting, left sympathetic therapeutic block by means of thoracoscopy in patients with heart failure has shown promising results. ${ }^{12}$ The clinical improvement and the better left ventricular function observed in patients undergoing this procedure over the first six months of follow-up have been similar to those documented from using other well established procedures for treating chronic heart failure. Findings from imaging examinations using 123I-metaiodobenzylguanidine have indicated that bilateral upper thoracic sympathectomy mildly suppresses the activation of the sympathetic nerve system, like in beta-blocker therapy.

Other procedures such as partial left ventriculectomy and dynamic cardiomyoplasty have shown controversial results and have not become established as widely used or easily accepted procedures for treating heart failure. ${ }^{9}$

Within this context, the natural history of heart failure has given rise to highly unfavorable prognoses and low quality of life among such patients. The search for methods that provide alternatives or are complementary to drug treatment, and which might modify the course of heart failure, is one of today's major challenges within cardiology, if not the greatest challenge, and is a hot topic within the field of cardiovascular surgery. ${ }^{9,13}$

\section{REFERENCES}

1. Jessup M, Núñez-Gil IJ. Heart failure and mechanical circulatory assist devices: new answers to old questions. Rev Esp Cardiol. 2008;61(12):1231-5.

2. Barretto ACP, Del Carlo CH, Cardoso JN, et al. Re-hospitalizações e morte por insuficiência cardíaca: índices ainda alarmantes [Hospital readmissions and death from heart failure: rates still alarming]. Arq Bras Cardiol. 2008;91(5):335-41.

3. Shroyer AL, Collins JF, Grover FL. Evaluating clinical applicability: the STICH trial's findings. J Am Coll Cardiol. 2010;56(6):508-9.

4. Yoshimori DY, Cipriano Júnior G, Mair V, Branco JNR, Buffolo E. Avaliação e seguimento em médio prazo em candidatos a transplante cardíaco submetidos a exercício de baixa intensidade [Assessment and medium-term follow up of heart transplant candidates undergoing low-intensity exercise]. Rev Bras Cir Cardiovasc. 2010;25(3):333-40.

5. Coronel CC, Bordignon S, Bueno AD, Lima LL, Nesralla I. Variáveis perioperatórias de função ventilatória e capacidade física em indivíduos submetidos a transplante cardíaco [Perioperative variables of ventilatory function and physical capacity in heart transplant patients]. Rev Bras Cir Cardiovasc. 2010;25(2):190-6.

6. Helito RAB, Branco JNR, D'Innocenzo M, Machado RC, Buffolo E. Qualidade de vida dos candidatos a transplante de coração [Quality of life in heart transplant candidates]. Rev Bras Cir Cardiovasc. 2009;24(1):50-7.

7. Nicolini F, Gherli T. Alternatives to transplantation in the surgical therapy for heart failure. Eur J Cardiothorac Surg. 2009;35(2):214-28.

8. Freitas Júnior AF, Bacal F, Oliveira Júnior JL, et al. Impacto do sildenafil sublingual na hipertensão pulmonar de pacientes com insuficiência cardíaca [Impact of sublingual sildenafil on pulmonary hypertension in patients with heart failure]. Arq Bras Cardiol. 2009;92(2):122-6.

9. Bocchi EA, Braga FG, Ferreira SMA, et al. III Diretriz Brasileira de Insuficiência Cardíaca Crônica. [III Brazilian Guidelines on Chronic Heart Failure]. Arq Bras Cardiol 2009;93(1 Suppl 1):3-70.

10. Rodrigues ACT. Terapia de ressincronização cardíaca: há algo de novo no front? [Cardiac resynchronization therapy: is there any news?]. Arq Bras Cardiol. 2010;94(1):2-3.

11. Domian IJ, Buikema JW, de Boer RA, van der Meer P. Stem cells in heart failure. Eur J Heart Fail. 2010;12(7):642-4.

12. Pêgo-Fernandes PM, Moreira LFP, Souza GEC, et al. Bloqueio simpático esquerdo por videotoracoscopia no tratamento da cardiomiopatia dilatada [Endoscopic left sympathetic blockade in the treatment for dilated cardiomyopathy]. Arq Bras Cardiol. 2010;95(6): 685-90.

13. Pirk J. The role of cardiac surgery in treatment of chronic heart failure. Physiol Res. 2009;58 Suppl 2:S167-9

14. Rodrigues da Silva P. Transplante cardíaco e cardiopulmonar: 100 anos de história e 40 de existência [Cardiopulmonary and heart transplantation: 100 years of history and 40 years of existence]. Rev Bras Cir Cardiovasc. 2008;23(1):145-52.

15. Gelape CL, Nunes MCP, Bráulio R, et al. Pressão pulmonar aferida pela ecocardiografia em pacientes chagásicos indicados para transplante cardíaco [Pulmonary pressure by echocardiophy in chagasic patients on heart transplant waiting list]. Revista Brasileira de Cirurgia Cardiovascular. 2011;26(1):54-60. Available from: http://www.rbccv.org.br/detaIhe_artigo.asp?id=1423. Accessed in 2011 (Apr 12).

16. Dinkhuysen JJ, Cipullo R, Contreras $\mathrm{C}$, et al. Teste farmacológico pré-implante na hipertensão pulmonar elevada e fixa em candidatos a transplante heterotópico [Farmacologic test pre implants in hypertension pulmonary elevated and still in candidates to heterotopic transplantation]. Rev Bras Cir Cardiovasc. 2010;25(3):371-6.

17. Moreira LFP, Benício A. Assistência circulatória mecânica: uma grande lacuna na cirurgia cardíaca brasileira [Mechanical circulatory support: a great gap in Brazilian cardiac surgery]. Rev Bras Cir Cardiovasc. 2010;25(4):X-XII.

18. Dinkhuysen JJ, Andrade A, Contreras C, et al. Estudo experimental da aplicação do ventrículo artificial eletromecânico pulsátil implantável [Experimental study of pulsatile implantable electromechanical artificial ventricle]. Revista Brasileira de Cirurgia Cardiovascular. 2011;26(1):76-85. Available from: http://www.rbccv.org.br/detalhe_artigo.asp?id=1426. Accessed in 2011 (Apr 12).

19. Galantier J, Moreira LFP, Benício A, et al. Desempenho hemodinâmico e resposta inflamató ria durante o uso do DAV-InCor como ponte para o transplante [Hemodynamic performance and inflammatory response during the use of VAD-InCor as a bridge to transplant]. Arq Bras Cardiol. 2008;91(5):327-34.

20. Benfatti RA, Pontes JCDV, Gomes OM, et al. Substituição valvar mitral com papilopexia cruzada e constrição anular em pacientes com insuficiência cardíaca [Mitral valve replacement with crossed papillopexy and annular constriction in heart failure patients]. Rev Bras Cir Cardiovasc. 2008;23(3):372-7.

21. Pêgo-Fernandes PM, Moreira LFP, Stolf NAG, et al. Assistência circulatória com bomba centrífuga no choque cardiogênico após cirurgia com extracorpórea [Assisted circulation with centrifugal pump in cardiogenic shock after surgery with extracorporeal]. Rev Bras Cir Cardiovasc. 1991;2011;6(2):104-8.

22. Pêgo-Fernandes PM, Moreira LFP, Dallan LA, et al. Uso de bomba centrífuga no pós-operatório de cirurgia cardíaca [Use of centrifugal pump in the postoperative period of cardiac surgery]. Rev Bras Cir Cardiovasc. 1992;7(4):263-8.

23. Pêgo-Fernandes PM, Fabri HA, Moreira LFP, et al. Avaliação da ação concomitante do balão intra-aórtico e da bomba centrífuga na assistência ao ventrículo esquerdo: estudo experimental em cães [Evaluation of intraaortic balloon pump associated with centrifugal pump for left ventricular assistance: an experimental study in dogs]. Rev Bras Cir Cardiovasc. 1998:13(4):357-67.

24. Pêgo-Fernandes PM, Moreira LFP, Jatene FD, et al. Circulação assistida com bomba centrífuga no choque cardiogênico após cirurgia com extracorpórea [Assisted circulation with centrifugal pump for cardiogenic shock after extracorporeal surgery]. Arq Bras Cardiol. 1991;56(4):313-6.

25. Pêgo-Fernandes PM, Stolf NAG, Leirner AA, Moreira LFP, Jatene AD. Circulação assistida mecânica como ponte para o transplante cardíaco [Mechanical circulatory support as a bridge to cardiac transplantation]. Arq Bras Cardiol. 1994;63(3):255-9. 
26. Oliveira JVC, Vicente WVA, Rodrigues AJ, et al. Cirurgia da insuficiência mitral no tratamento da insuficiência cardíaca avançada [revisão] [Mitral insufficiency surgery to treat advanced heart failure [review]]. Rev Bras Cir Cardiovasc. 2009;24(4):540-51.

27. Veiga VC, Rojas SSO, Souza FSO, et al. Avaliação ecocardiográfica da terapia de ressincronização cardíaca: dois anos de seguimento [Echocardiographic assessment of cardiac resynchronization therapy: two-year follow-up period]. Arq Bras Cardiol. 2010;94(1): 119-26.

28. Wikstrom G, Blomström-Lundqvist C, Andren B, et al. The effects of aetiology on outcome in patients treated with cardiac resynchronization therapy in the CARE-HF trial. Eur Heart J. 2009;30(7):782-8.

29. Almeida RMS. Remodelamento reverso cirúrgico do ventrículo esquerdo: seguimento de 111 meses [Surgical reverse remodelling of the left ventricle: 111 months of follow-up]. Rev Bras Cir Cardiovasc. 2009;24(4):470-7.

Sources of funding: None

Conflict of interest: None

Date of first submission: April 7, 2011

Last received: April 7, 2011

Accepted: April 15, 2011

Address for correspondence:

Paulo Manuel Pêgo-Fernandes

Instituto do Coração (InCor) Secretaria do Serviço de Cirurgia Torácica

2andar - bloco 2 - sala 9

Av. Dr. Enéas de Carvalho Aguiar, 44

Cerqueira César - São Paulo (SP) - Brasil

CEP 05403-000

Tel. (+55 11) 3069-5248

E-mail: paulopego@incor.usp.br 